\title{
PRELIMINARY REMARKS ON ENIGMATIC "WHITE CASING LIMESTONE" FROM SAQQARA ARCHAEOLOGICAL SITE IN EGYPT
}

\author{
Fabian Welc ${ }^{1}$, Ewa Malata ${ }^{2}$, Leszek Marks ${ }^{3}$, Barbara Studencka ${ }^{4}$, Barbara Olszewska ${ }^{5}$ \\ ${ }^{1}$ Institute of Archaeology, Cardinal Stefan Wyszynski University in Warsaw, Wóycickiego 1/3, bud. 23, \\ 01-938 Warszawa, Poland, e-mail:f.welc@uksw.edu.pl \\ ${ }^{2}$ Institute of Geological Sciences, Jagiellonian University, Oleandry 2A, 30-063 Kraków, Poland, \\ e-mail:ewa.malata@uj.edu.pl \\ ${ }^{3}$ Faculty of Geology, Warsaw University, Żwirki $i$ Wigury 93, 02-089 Warszawa, Poland, \\ e-mail:leszek.marks@uw.edu.pl \\ ${ }^{4}$ Polish Academy of Sciences, Museum of the Earth in Warsaw, Aleja Na Skarpie 20/26, 27, \\ 00-488Warszawa, Poland, e-mail: bstudencka@go2.pl \\ ${ }^{5}$ Polish Geological Institute, Carpathian Branch in Cracow, Skrzatów 1, 31-560 Kraków, Poland, \\ e-mail: barbara.olszewska@pgi.gov.pl
}

\begin{abstract}
Saqqara is one of the famous archaeological sites in the world. There is the oldest stone pyramid built by pharaoh Djoser from the Third Dynasty (around 4600 yrs BP). The components of his funerary complex were constructed of a characteristic creamish-white limestone of relatively great solidity, connected in archaeological literature with the white casing limestone from Saqqara. A source of this stone has remained so far a mystery. An extensive geological survey and other research has failed to identify any outcrops of such limestone in the vicinity of Saqqara. Preliminary results of examination of fossils from relevant rock samples of the white Saqqara limestone are presented, supplemented with discussion of current opinions concerning its origin and probable stratigraphic setting.
\end{abstract}

Key words: limestone, archaeology, Step Pyramid, Djoser, Old Kingdom

\section{INTRODUCTION}

The archaeological site in Saqqara is located $23 \mathrm{~km}$ south of Cairo and constitue fragment of the Memphite necropolis (Fig. 1). The cemetery was first used during the First Dynasty ( $c$ a $3100 \mathrm{yrs} \mathrm{BC}$ ). It contains thousands of tombs from almost all periods in the history of ancient Egypt, but the structure that dominates the landscape is a Step Pyramid built by the pharaoh Djoser Netjerykhet of the Third Dynasty (ca 2600 yrs BC). This pyramid was the first monumental architectural complex in Egypt raised entirely of stone. The tomb of Djoser was the centerpiece of a vast funerary complex that included a number of cult structures surrounded by a monumental enclosure wall of limestone about $10 \mathrm{~m}$ in high (Figs 2-4).

The location of quarries supplying the stone building material for the Step Pyramid has not been known until recent times. Investigations in 2009-2010 immediately to the west of the pyramid complex produced evidence in favor of a suggestion proposed already by Klemm \& Klemm (2008) that stone blocks were quarried somewhere in the near vicinity (Welc, 2011).

Particular components of the Djoser's funerary complex, including the step pyramid, were built of the Upper Eocene marly and sandy limestones, classified as the Saqqara
Member in the Maadi Formation of the Mokattam Group (cf. Youssef et al., 1984; Ago et al., 2003). The local limestone was used mainly for the core of walls of cult structures and tombs, whereas the outer wall facings of the tombs as well as the pyramid itself were constructed of a characteristic creamish-white limestone of relatively larger resistance, referred in archaeological literature to the white casing limestone from Saqqara (Figs 3, 4; Klemm \& Klemm, 2008). The enclosure wall of the pyramid complex was built entirely of this stone (Fig. 5; cf. Firth \& Quibell, 1935).

This white, compact limestone was greatly appreciated as a casing stone by the ancient builders due to its properties, mainly hardness and weather-resistance. Archaeological evidence attests its extensive use in Egyptian architecture from the Third Dynasty (Aston et al., 2000). However, derivation area of this stone has remained so far a mystery. Extensive geological survey and research in the Saqqara region have failed to identify any outcrops of this limestone (Klemm \& Klemm, 2010). During the Fourth Dynasty this stone was replaced with another, very similar one but much less resistant limestone quarried at Tura and Maasara on the eastern bank of the Nile (Fig. 1).

The white casing limestone was described as compact, fine grained and yellowish stone but without structural diagnostic traits visible with a use of a hand lens (Klemm \& 


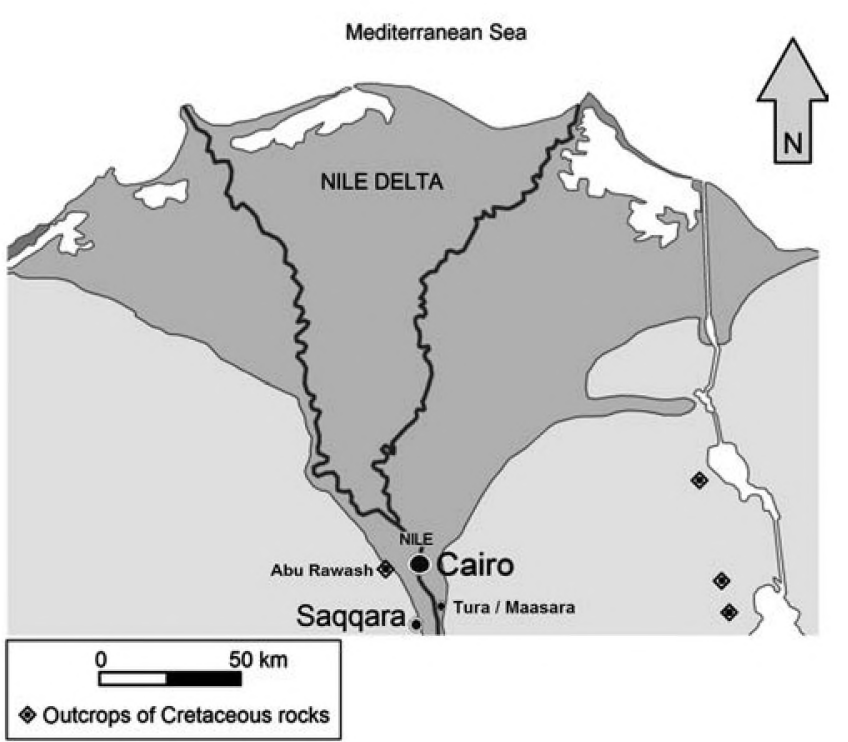

Fig. 1. General map of the Nile Delta region.

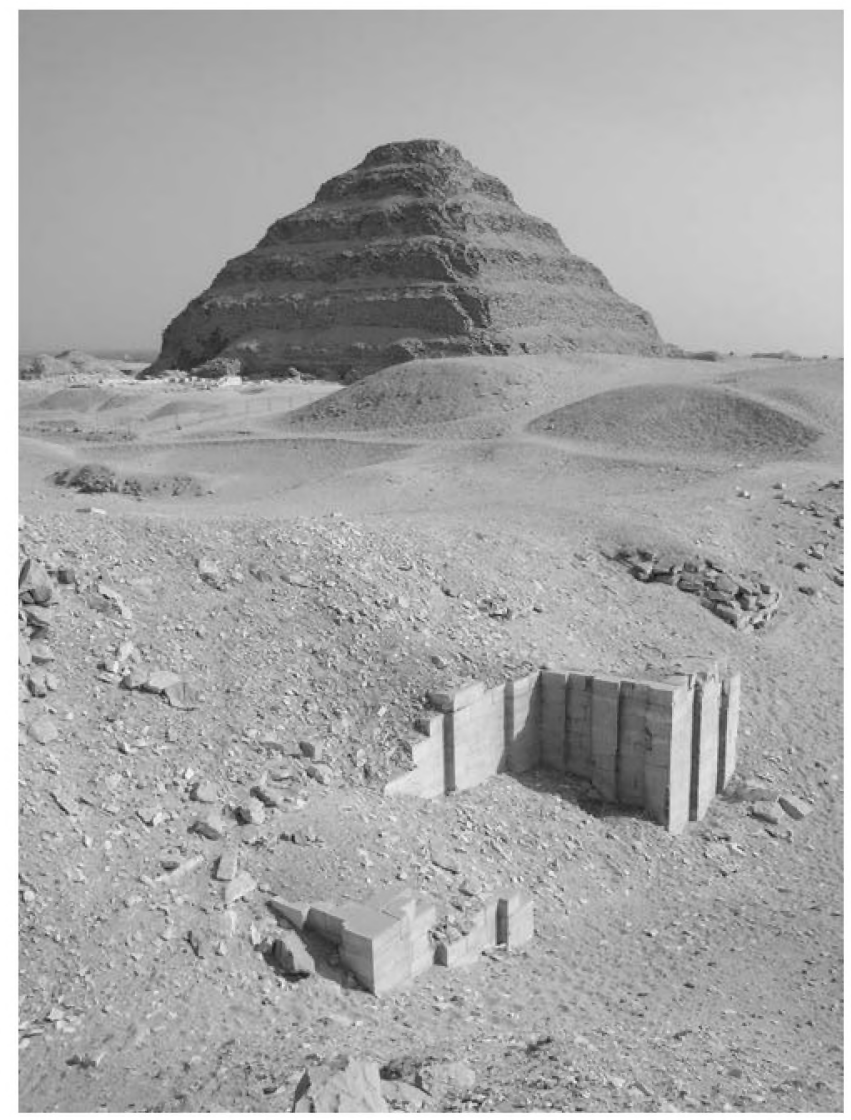

Fig. 2. Remains of enclosure wall surrounding the Step Pyramid complex, view form north-west (photo F. Welc).

Klemm, 2008: 57, pl. 28). At a microscopic level this stone consists of fine micritic matrix with clay minerals and relatively few fossils (5-10\%). It is a typical mudstone according to the general classification of carbonate rocks (Dunham, 1962). Organic detritus is predominated by planktonic and benthonic foraminifera, echinoderm spines and very fine pieces of shells. Basing on the foraminifera analyses of $\mathrm{M}$.

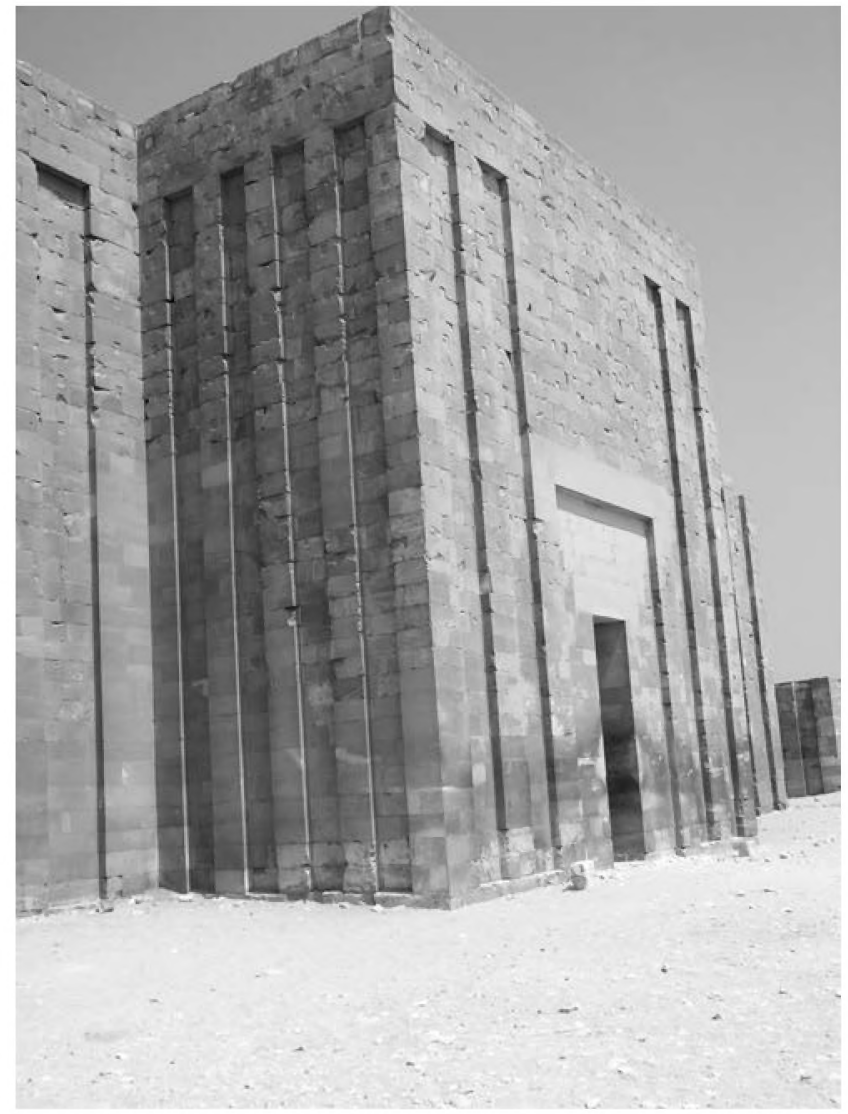

Fig. 3. Reconstruction of the main entrance to the Step Pyramid complex. The structure of the wall is very well visible (photo F. Welc).

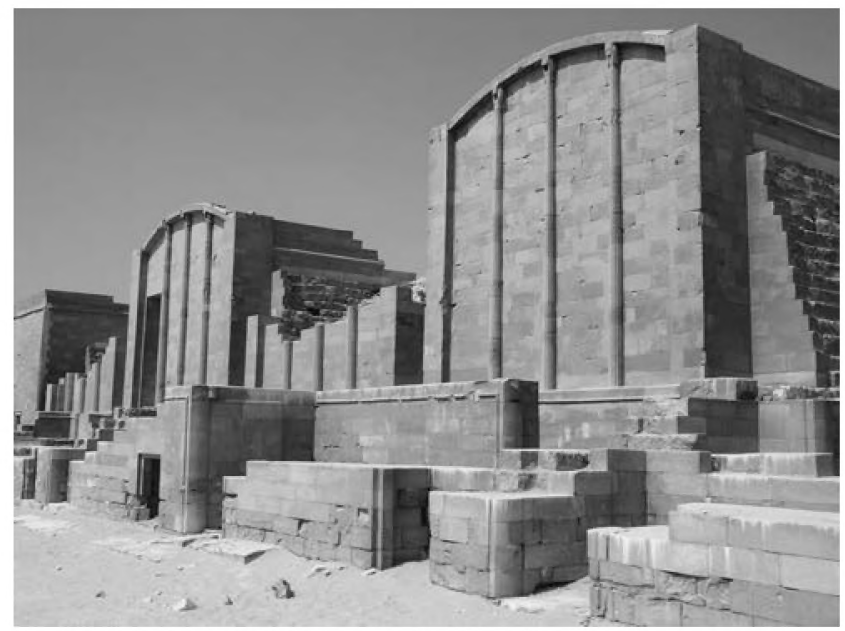

Fig. 4. Cult chapels reconstructed inside Step Pyramid temenos. All these structures were cased by small blocks of the white compact limestone, whereas interior was built with local sandy and marly limestone (photo F. Welc).

Boukhary's (Ain Shams University), the white limestone from Saqqara can be attributed to the Bartonian stage of the uppermost Eocene, locating it in later phases of the local Saqqara stratigraphic sequence (Klemm \& Klemm, 2008).

Some differences concerning stratigraphy of Eocene limestones from Egypt can result from different approach to the position of the Bartonian within the Eocene as it was ex- 
pressed for example by Tawadros (2011: 729). He mentioned that Egyptian geologists prefer to consider the Bartonian as the Upper Eocene while the contemporary subdivisions locate this stage within the Middle Eocene (Gradstein et al., 2004, 2012).

Exact dating of the white limestone is difficult because of its significant diagenesis and recrystallisation. Klemm and Klemm (2010) were of the opinion that this stone was evidently unlike anything encountered in Saqqara and adjoining area, meaning in particular the macroscopically similar limestone from Tura and Maasara on the eastern bank of the Nile. Stratigraphic setting of the Tura and Maasara limestones locate them in the Observatory Formation of the Mokattam Group of the Helwan Facies (upper Lutetian of the Middle Eocene, cf. Said 1990: 462). The white limestone from Saqqara, compared to both these formations is much more dense, fine-grained and compact with no macroscopically visible fossil remains. According to Klemm \& Klemm (2010: 23), neither the fossil record nor the internal structure of this limestone could by any means allow it to be confused with the limestones from Tura and Maasara.

A quantitative analysis of $\mathrm{Mg} / \mathrm{Fe}$ and $\mathrm{Mg} / \mathrm{Sr}$ content ratios in samples of white limestone from Saqqara, that is from the Step Pyramid complex, unfinished complex of Sekhemhet and the pyramid in Medum (archaeological site near Fayoum Oasis), produced almost identical distribution fields. It suggests that the stone has not been exploited any longer at the beginning of the Fourth Dynasty and it was replaced by the limestone of much poorer quality from Tura and Maasara (Klemm \& Klemm, 2010: 23, fig. 15).

Assuming the Upper Eocene dating suggested by M. Boukhary (cf. Klemm \& Klemm, 2008) and its stratigraphic position, the white limestone beds should have been very easy accessible to ancient miners especialy on the Saqqara plateau. So far, however, no outcrops of this or even similar rocks have been found, making it all more surprising when one considers that blocks of this stone are scattered practically all over the necropolis area.

Moreover, examination of many excavated Old Kingdom burial shafts has given a perfect opportunity to trace local lithological changes in the limestone massif forming the Saqqara plateau, but has failed hitherto to locate any quarried beds of white, compact limestone. Klemm \& Klemm (2010) explain it by the exhaustion of these rock beds during the Third Dynasty. Starting from the pharaoh Sneferu (Fourth Dynasty, around 4500 yrs BP) this rock was replaced by the Tura and Maasara limestones, which remained in use until the end of Pharaonic Egypt.

\section{NEW INVESTIGATIONS ON THE WHITE CASING SAQQARA LIMESTONE}

\section{Micropaleontological analyses}

Preliminary results of micropaleontological analyses of some samples of white limestone from Saqqara, carried out by E. Malata and B. Olszewska, contributed new important data to the question of dating and origin of this enigmatic rock.

Paleontological investigations have been carried out on small rock samples originated from the enclosure limestone

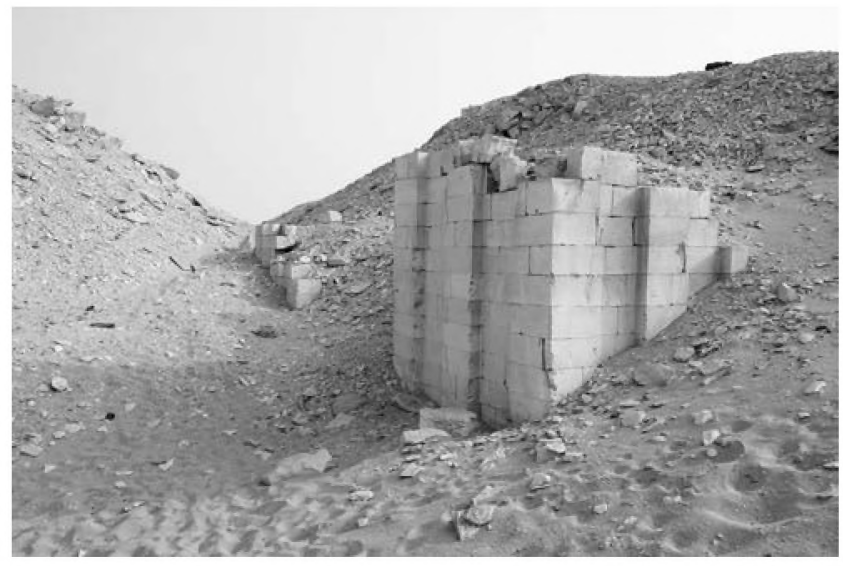

Fig. 5. Close up of the remains of the enclosure wall surrounding the Step Pyramid complex, view from the north-west (photo F. Welc).

wall around the funerary complex of Netjerykhet (collected from the ground surface). Standard thin sections were prepared and then have been analyzed using Nikon Polarizing Microscope Eclipse LV100POL. The Nikon digital camera DS-Fi1 and the camera control unit were used to take photos.

The thin section analyses have revealed the presence of fossil assemblages consisting of small, juvenile ammonites (Fig. 6A-H), thin-shelled bivalves (Fig. 6M), ostracods (Fig. 6I-M) as well as moulds of small bivalves (Fig. $6 \mathrm{~N}$ ) and sponge spicules. Among microfossils, small foraminifera are relatively the most numerous. They are represented mainly by planktonic forms, which are important for age determination of the rock sample. Favusella washitensis (Carsey) seems to be the most characteristic taxon in the studied thin sections (Fig. 7A-E). Serial planktic foraminifera are represented by biserial and triserial morphotypes. Axial and longitudinal sections of biserial form (Fig. 7I, J) have been attributed to Heterohelix moremani (Cushman). Two-chambered transversal sections (Fig. 7K, L) represent the genus Heterohelix Ehrenberg, 1843. Three-chambered transversal sections (Fig. 7M, N) indicate Guembelitria cf. cenomana Keller. Longitudinal sections passing through two (Fig. 7O) and three chambers (Fig. 7P) belong, most probably, to juvenile forms of this species. Axial sections of the planispiral form (Fig. 7F-H) belong to the genus Globigerinelloides Cushman and ten Dam, 1948. Single, axial oblique section of Hedbergella cf. delrioensis (Carsey) (Fig. 8A) as well as Praeglobotrunaca sp. (Fig. 8D) have been also found. The specimens B and C (Fig. 8) resemble axial sections of the genus Planomalina Loeblich and Tappan, 1946. The specimen $\mathrm{C}$ (Fig. 8) represents rather the interior infill of the shell while in the specimen B a shell of the last chamber can be observed.

The stratigraphic ranges of the identified planktonic foraminifera have been based on Caron (1985) and Premoli Silva \& Sliter (2002). Favusella washitensis is a taxon of the uppermost Aptian-early Cenomanian. A stratigraphic range of Heterohelix moremani is the uppermost Albian-Coniacian. The first occurrence (FO) of Guembelitria cenomana is noticed in the uppermost Albian and last occurrence (LO) at the Cenomanian/Turonian boundary. The genus Globigerinelloides is known from the Barremian throughout the Late 

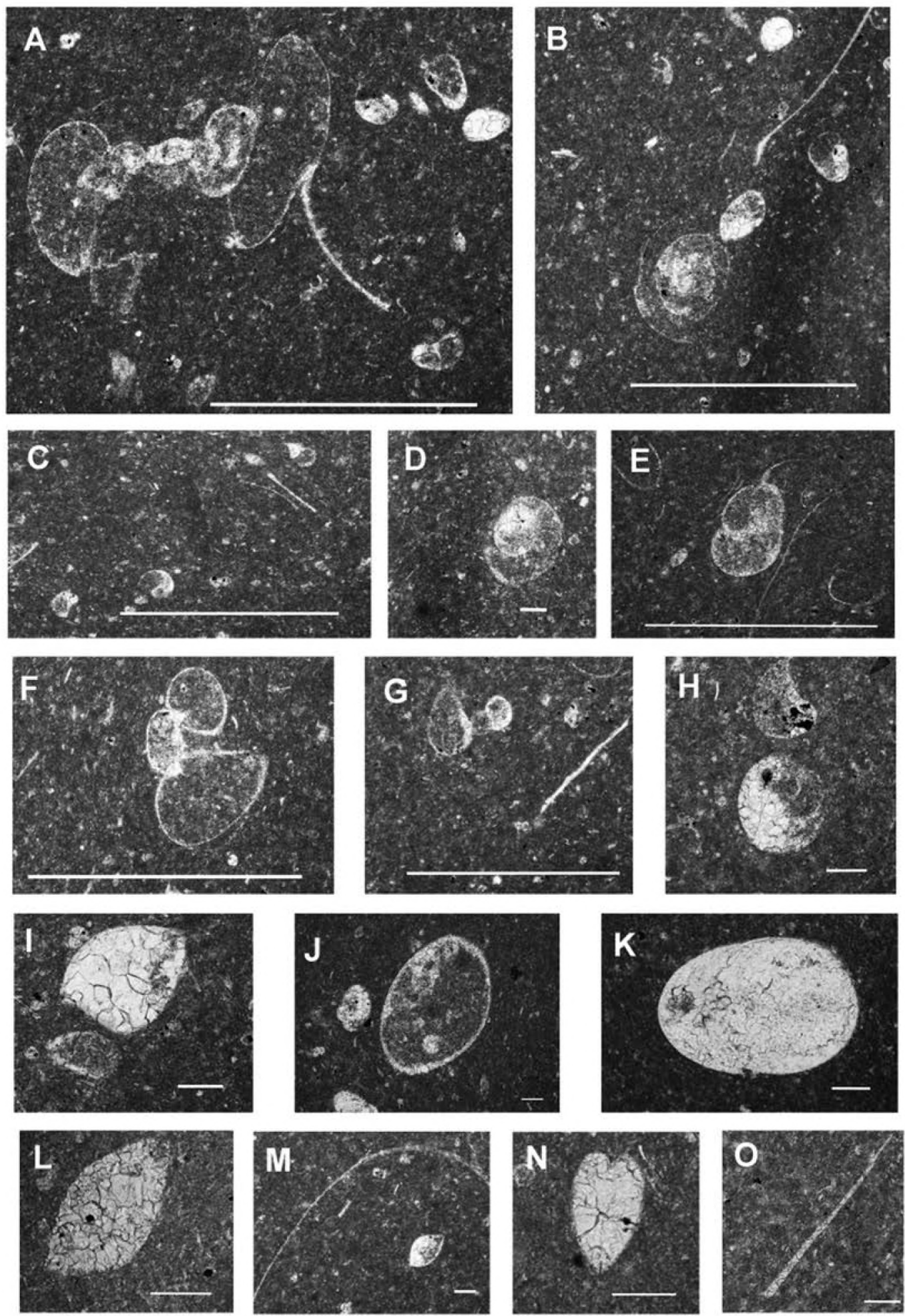

Fig. 6. A-H - small (juvenile) ammonites (A, F, G - transverse sections and B-H - parallel/oblique sections); I, J - ostracods; K, L moulds of ostracods, $\mathbf{M}$ - ostracod and thin-shelled bivalve (filament), $\mathbf{N}$ - mould of ? a small bivalve, $\mathbf{O}$-sponge spicule; $\mathrm{A}-\mathrm{C}, \mathrm{E}-\mathrm{G}-\mathrm{scale}$ bars $=1 \mathrm{~mm} ; \mathrm{D}, \mathrm{H}-\mathrm{O}-$ scale bars $=100 \mu \mathrm{m}$. 

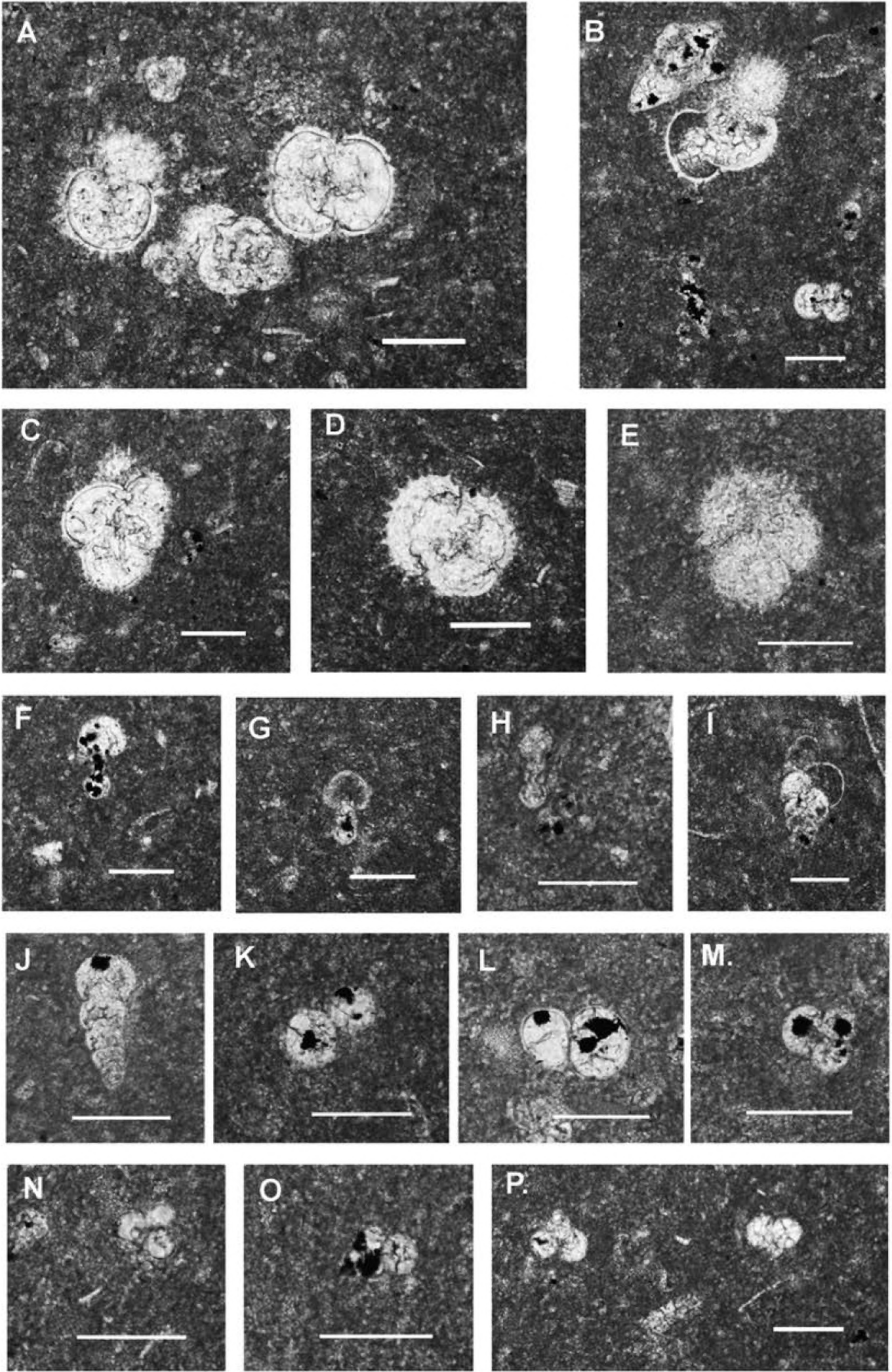

Fig. 7. A, C-E - Favusella washitensis (Carsey); B - Favusella washitensis (Carsey), benthonic form and Guembelitria cf. cenomana Keller; F, G - Globigerinelloides sp. 1 (? bentonensis); $\mathbf{H}-$ Globigerinelloides sp. 2; I, J - Heterohelix moremani (Cushman); K, L ? Heterohelix sp.; M-P - Guembelitria cf. cenomana Keller - small, juvenile forms; all scale bars $=100 \mu \mathrm{m}$. 

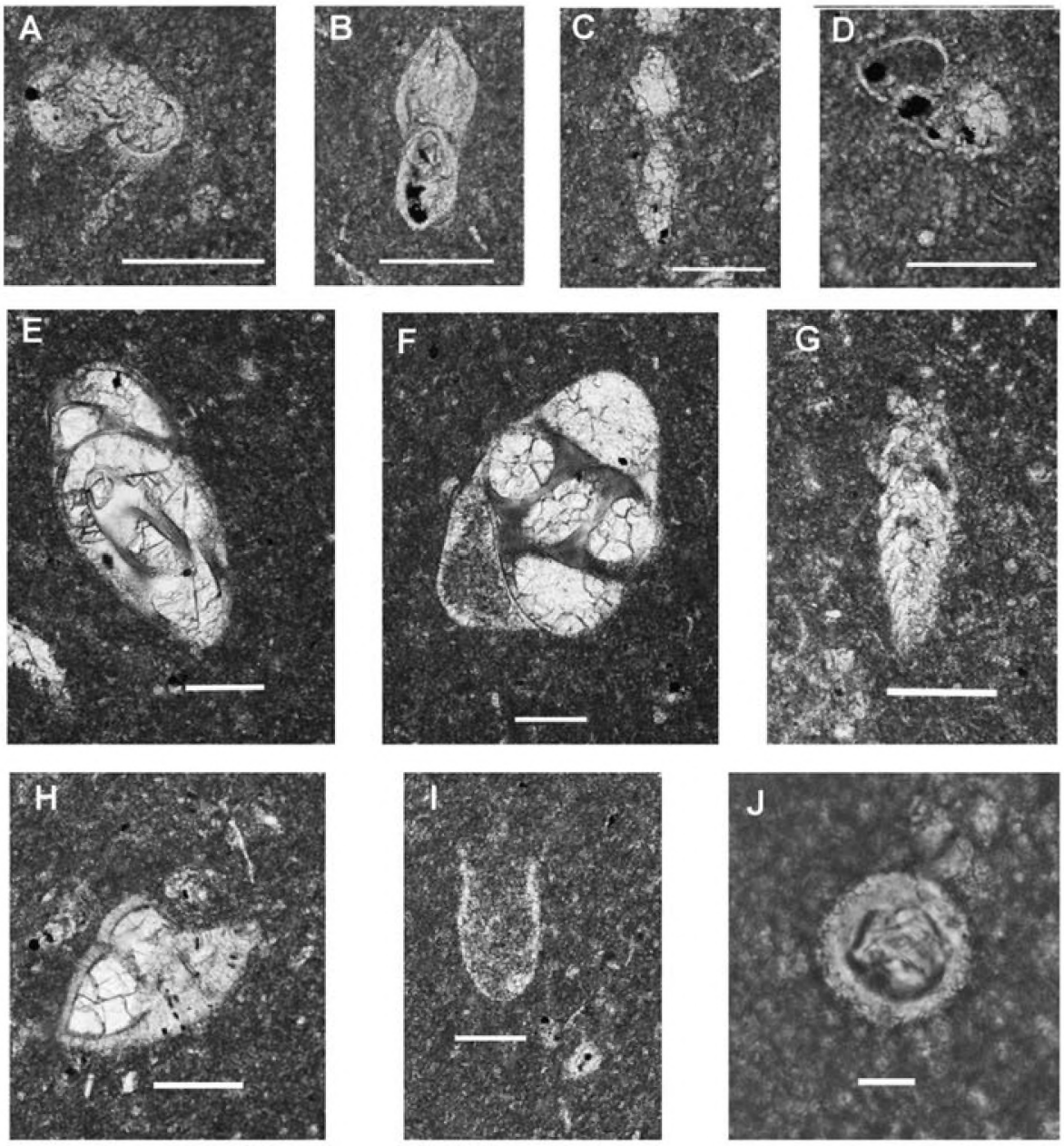

Fig. 8. A - Hedbergella cf. delrioensis (Carsey); B, C - Planomalina sp.; D - ? Praeglobotruncana sp.; E - Miliolidae s.l.; F Quinqueloculina sp.; $\mathbf{G}$ - benthic foraminifera (?Eouvigerina or ? Pseudouvigerina); $\mathbf{H}$ - benthic foraminifera (suborder Rotaliina); I ? Colomiella sp., J - Orthopithonella sphaerica (Kaufman); A-I - scale bars $=100 \mu \mathrm{m}, \mathrm{J}-$ scale bar $=10 \mu \mathrm{m}$.

Cretaceous. Hedbergella delrioensis ranges from Barremian to Santonian while Praeglobotruncana appears in the upper part of Albian and disappears in the early Turonian. The genus Planomalina is known from the Aptian and late Albian.

Benthic small foraminifera are rare in the examined material and are represented by Quinqueloculina sp. and some other miliolids (Fig. 8E, F) as well as poorly preserved forms of the suborder Rotaliina (Fig. 8G, H). Apart from the foraminifera, single specimens of calpionellids and calcareous dinoflagellate cysts have been also observed in the studied thin sections. The specimen I (Fig. 8) may represent lorica of a new species of Collomiella (personal communication of Professor Daniela Reháková from Comenius University, Bratislava). However, it would be necessary to find more examples to make determination reliable. The genus Colomiella belongs to hyaline calpiollenids and its first occurrence was noticed in the early Albian (Reháková, 2000). Orthopithonella sphaerica (Kaufman) (Fig. 8J) belongs to calcareous dinoflagellate. This taxon is reported from the Albian through Late Cretaceous (Keupp, 1992).

Smear slide from the same rock sample was examined for the nannofloral content by Dr. M. Kędzierski (Institute of
Geological Sciences of the Jagiellonian University). Calcareous nannofossils are very rare and show strong overgrowth due to considerable amount of carbonates. Only one, long ranging taxon Watznaueria barnesiae, known from Late Jurassic through Late Cretaceous, has been identified. This taxon is usually the least soluble Cretaceous species (PerchNielsen, 1985). The other noticed specimen resembled genus Eprolithus that is known from the uppermost Aptian to Coniacian (Varol, 1992).

Considering the stratigraphic ranges of the most characteristic and best preserved taxa within the identified microfossils, the analyzed fossil assemblage suggests the uppermost Albian - early Cenomanian as the possible age. The fossil content, particularly juvenile ammonites and relative dominance of planktonic foraminifera, suggests rather open marine conditions.

\section{Bivalve studies}

The white Saqqara limestone contains some of bivalve fossils macroscopically visible in the stone structure in the form of characteristic cross-sections of shells (Fig. 9). Speci- 
mens of fossil bivalves have been studied by Dr. B. Studencka. Material for bivalve studies consisted of 3 articulated shells and 3 cross-sections embedded in pelitic matrix of the stone (Fig. 10). The examined specimens belong to the family Lucinidae Fleming, 1828 and represent a single taxon of Lucina genus.

The shells are usually $38-40 \mathrm{~mm}$ long, rather solid, subcircular in outline (length/height ratio 1.1) almost equilateral and moderately convex (Fig. 10). Small, prosogyrate beaks just before the midline, slightly project above the dorsal margin. Anterior margin is convex, posterior margin obliquely truncated with a slight corner to the ventral margin. Ventral margin is well rounded. External surface is sculptured with numerous thin, more or less densely spaced commarginal lamellae. Postero-dorsal area is well-marked (smaller on the right valve) with stronger commarginal lamellae. Lunule is not visible due to the preservation state.

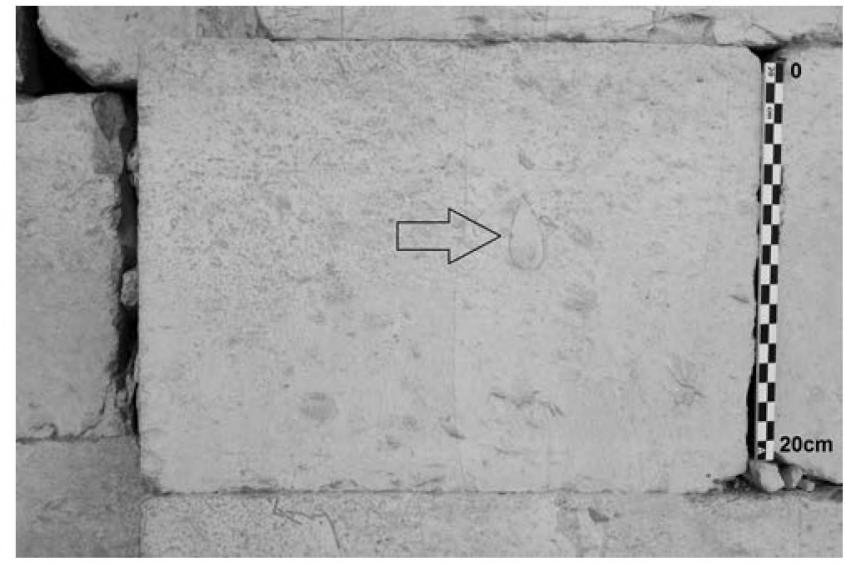

Fig. 9. Cross-section of bivalve shell still visible in the structure of the white limestone casing block of the enclosure wall (arrowed) (photo F. Welc).
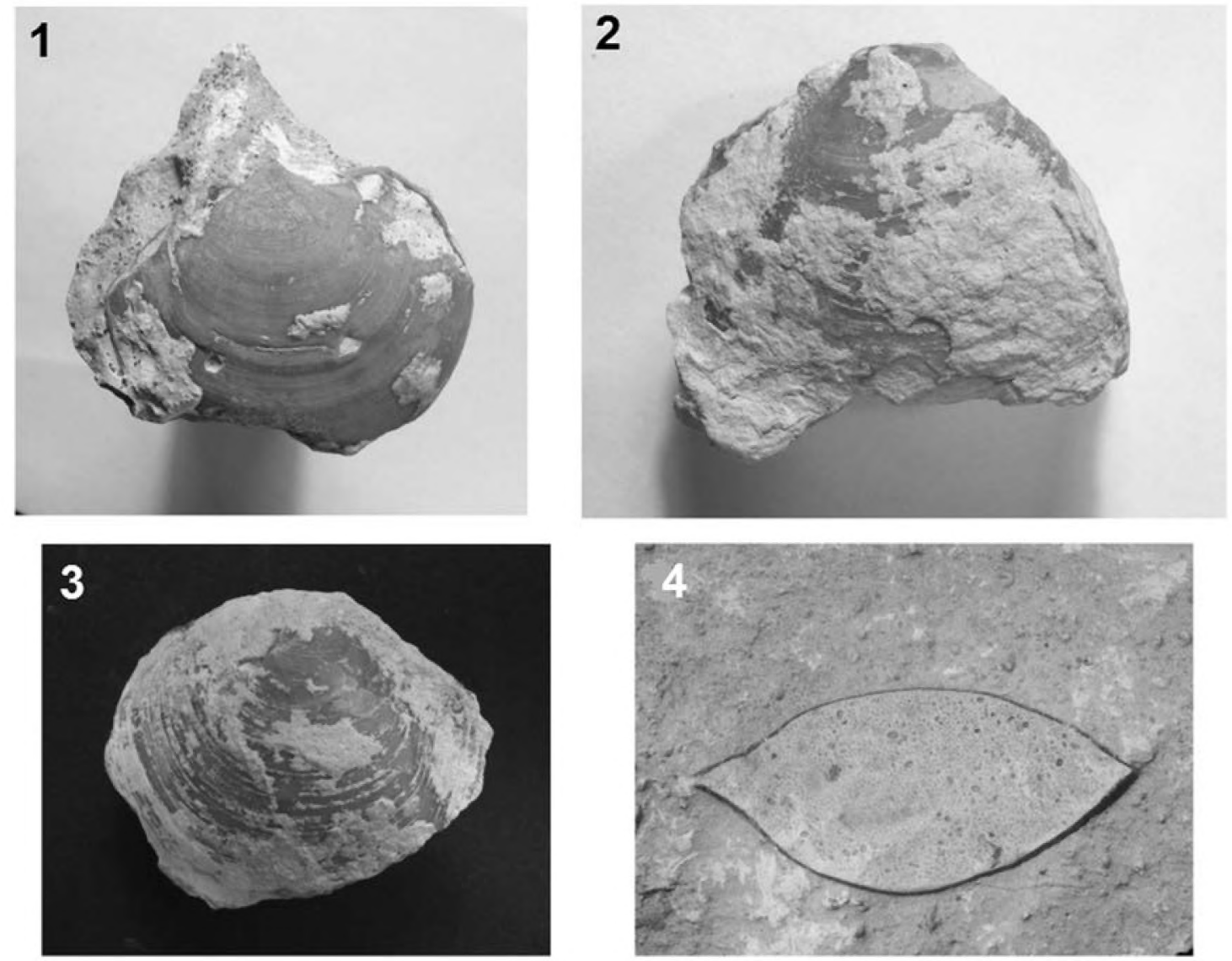

Fig. 10. Dimensions of the examined specimens of bivalves (in $\mathrm{mm}$ ): length - height - width; specimen 1: 44.0 - 36.5 - 17.0, specimen 2: $48.0-38.0-\sim 20.0$, specimen 3: $38.0-34.0-17.5$, specimen $4-48.0-\sim 27.0$ (photo B. Studencka).

Unfortunately, neither internal surface of the valve nor the hinge have been observed. The primarily aragonitic shell is strongly calcified. The investigated specimens are similar to the specimens determined by Abbass (1962: pp. 107-108, pl. 22, fig. 22) as Lucina (Dentilucina) dachelensis (Wanner, 1902) known from the Cretaceous (Campanian) of the Egyp- tian Western Desert. The similarities refer to shape of outline but they differ in the ornamentation. Individuals of Lucina (Dentilucina) dachelensis (Wanner, 1902) from Ain Amur and Kharga Oasis are ornamented with very low and thin commarginal lamellae with wider interspaces occupied by fine secondary threads. 

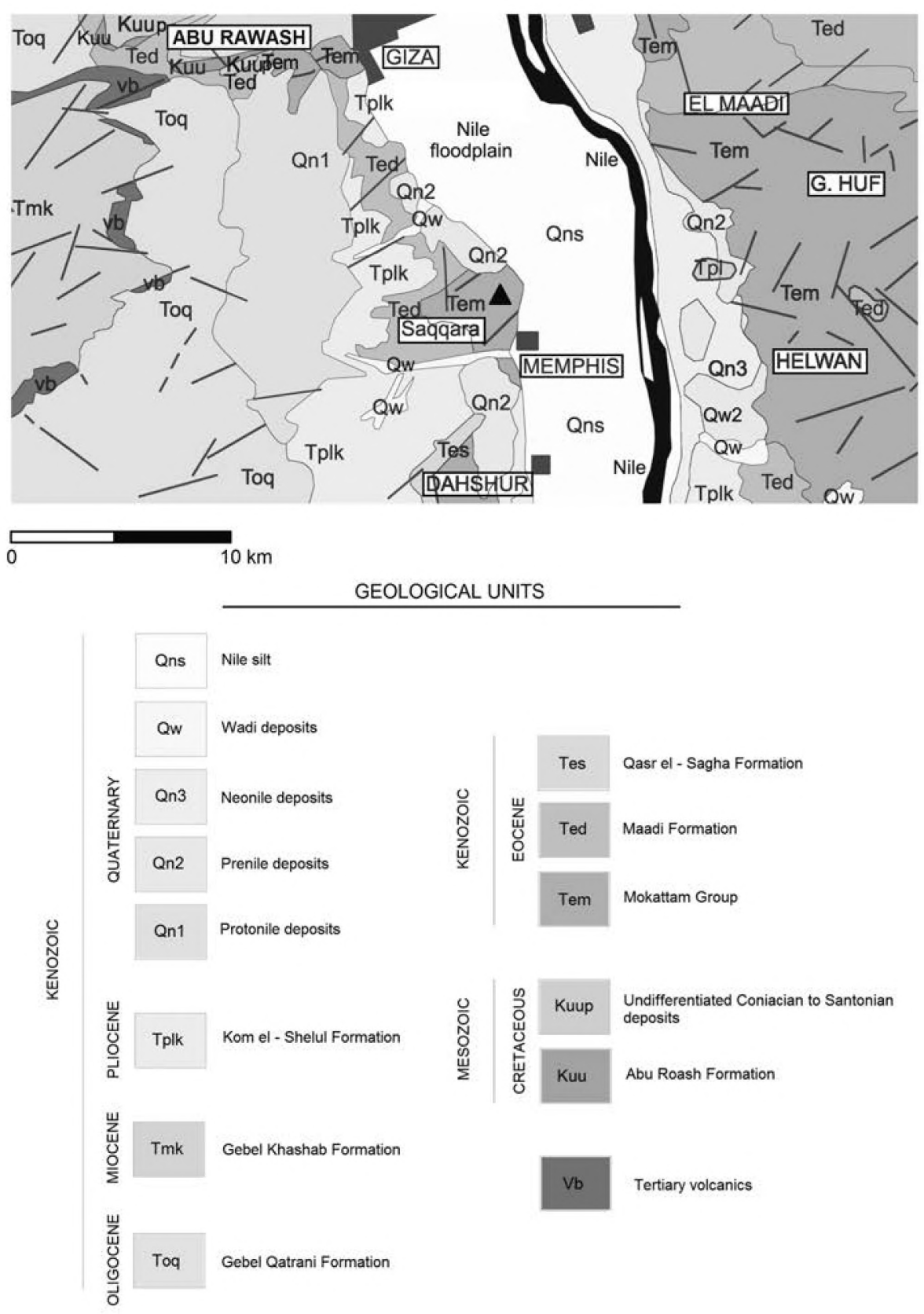

Fig. 11. Geological map of the southern Cairo region after Squyres et al. (1987).

\section{CONCLUSIONS}

Performed analyses of the samples of the white casing limestone from Sakkara, both in respect to the content of micro- and macrofauna, suggest the following conclusions concerning stratigraphic setting and potential place of extraction of this stone.

Micropaleontological analyses have revealed a presence of microfossils pointing to the uppermost Albian - early Cenomanian (dating of bivalves is not significant in this respect).

In Cairo region there is only a single outcrop of the Cretaceous limestone near Abu Rawash village, i.e. approximately $23 \mathrm{~km}$ north (Fig. 11) of Saqqara. According to the geologic map of Egypt in the scale 1:500000, Squyres et al.,
1987) the Abu Rawash Formation contains diverse sediments dated to the Senonian age: Coniacian and Santonian. These rocks overlie conformably the Baharia Formation (dolomites, sandy dolomites and fossiliferous sandstones of the late Cenomanian) and underlie the Khoman Formation (snow-white and chalky limestones with abundant chert bands of the upper Santonian and Maastrichtian). According to Hantar (1990: 313), the Abu Rawash Formation, $1000 \mathrm{~m}$ thick, is composed mainly of limestones with interbeds of shales and sandstones. Particular layers $(B-G)$ are dated to the late Cenomanian and Turonian-Santonian.

In regard to slightly younger age of the Cretaceous limestones from Abu Rawash, an open question still remains whether the so-called white casing Saqqara limestone could have been extracted there in the ancient times. In spite of in- 
tensive investigations of the area in question, no remains of an ancient pharaonic quarry have been found till now in $\mathrm{Abu}$ Rawash and its vicinity (Klemm \& Klemm, 2008).

On the other hand, we should also take into account a possibility of extraction of the white casing limestone directly on the Saqqara plateau, as it was already suggested by Klemm \& Klemm (2008: 57). In northern Egypt the top surface of the Cretaceous formations is morphologically very diversified due to upheavals and extensive depressions, additionally scarped by faults (cf. for example, Meshref, 1990). Vertical Electrical Sounding (VES) carried out in the Saqqara area detected large scale tectonic structures of downthrust type (El-Qady et al., 2005). Therefore, in some places within the Saqqara necropolis the Cretaceous limestones could have been accessible and mineable for ancient Egyptians. However, such assumption needs further fieldworks and laboratory analyses.

The presented results of preliminary paleontological studies suggest that the so called Saqqara casing limestone could be derived from the area of the Abu Rawash archeological site, where it has been probably quarried out.

\section{Acknowledgments}

We are very grateful to Rosemarie and Dietrich Klemm (Department of Environmental Geosciences, University of Münich, Germany) and James A. Harrell (Department of Environmental Sciences, University of Toledo, USA) for their reviews and comments which were very valuable for preparing the manuscript. Dr. B. Kolodziej (Institute of Geological Sciences of the Jagiellonian University, Poland) is thanked for discussion on microfacies. Prof. D. Rehakova (Comenius University, Bratislava) and dr M. Kędzierski (Jagiellonian University) are thanked for microfloral determinations.

\section{REFERENCES}

Abbass, H.L. 1962. A monograph on the Egyptian Cretaceous pelecypods. Palaeontological Series. Monograph No 1. Geological Museum of the Geological Survey and Mineral Research Department of the United Arab Republic, Cairo: $224 \mathrm{pp}$.

Ago, F., Bresciani, E., Gimmarusti, A. (Eds.) 2003. Geology of the Saqqara Site. In: The North Saqqara Archeological Site, Handbook for the Environmental Risk Analysis, Edizioni Plus Università di Pisa: 192-194.

Aston, B.G., Harrell, J.A., Shaw, I. 2000. Stone. In: P.T. Nicholson, I. Shaw (Eds.), Ancient Egyptian Materials and Technology. Cambridge University Press, Cambridge: 5-77.

Caron, M. 1985. Cretaceous planktic foraminifera. In: Bolli H.M., Saunders J.B. \& Perch-Nielsen K. (Eds.), Plankton Stratigraphy. Cambridge University Press, Cambridge: 17-86.

Dunham, R.J. 1962. Classification of carbonate rocks according to depositional texture. In: W.E. Ham (Ed.), Classification of Carbonate Rocks. American Association of Petroleum Geologists Memoir 1: 108-121.

El-Qady, G.M., Monteiro-Santos, F.A., Hassaneen, A. Gh., Trindade, L., 2005. 3D inversion of VES data from the Saqqara archaeological area, Egypt: a case study. Near Surface Geophysics 3 (4): 227-233.

Firth, C. M., Quibell, J. E. 1935. The Step Pyramid, 1. Le Caire: 9-10.

Gradstein, F.M., Ogg, J.G., Smith, A.G. (Eds) 2004. A Geologic Time Scale 2004. Cambridge University Press, Cambridge: $589 \mathrm{pp}$.

Gradstein, F.M., Ogg, J.G., Schmitz, M., Ogg, G. (Eds.) 2012. The Geologic Time Scale 2012, 2, Elsevier: 1144 pp.

Hantar, G. 1990. North Western Desert. In: Said, R. (Ed.), Geology of Egypt. Rotterdam-Brookfield: 293-319.

Keupp, H. 1992. Calcareous dinoflagellate cysts from the Lower Cretaceous of Hole 761C, Wombat Plateau, Eastern Indian Ocean. Proceedings of the ODP. Scientific results 122:497 pp.

Klemm, R. Klemm, D. 2008. Stones and quarries in Ancient Egypt. The British Museum Press: 40-57.

Klemm, D. Klemm, R. 2010. The stones of the pyramids, provenance of the building stones of the Old Kingdom Pyramids of Egypt. Walter de Gruyter, Berlin - New York: 12-26.

Meshref, W.M. 1990. Tectonic framework. In: R. Said (Ed.), The Geology of Egypt. Balkema, Roterdam-Brookfield: 113-155.

Perch-Nielsen, K. 1985. Mesozoic calcareous nannofossils. In: Bolli, H.M., Saunders J. B. \& Perch-Nielsen K. (Eds). Plankton Stratigraphy. Cambridge University Press, Cambridge: $329-426$.

Premoli Silva, I., Sliter, W.V. 2002. Practical manual of Cretaceous planktonic foraminifera. In: Premoli Silva, I., Rettori, R. (Eds.), International School on Planktonic Foraminifera 1. Course: Cretaceous. Dipartimento di Scienze della Terra, University of Perugia: $462 \mathrm{pp}$.

Reháková, D. 2000. Calcareous dinoflagellate and calpionellid bioevents versus sea-level fluctuations recorded in the WestCarpathian (Late Jurassic/Early Cretaceous) pelagic environments. Geologica Carpathica 51, 4: 229-243.

Said, R. 1990. Cenozoic. In: R. Said (Ed.), The Geology of Egypt. Balkema, Roterdam-Brookfield: 451-486.

Squyres, C.H., Robert, E., Handley, R., List, F.K., Pöhlmann, G., 1987. Geological map of Egypt 1:500,000. NH 36 SW, Beni Suef. Cairo, Conoco.

Tawadros, E. 2011. Geology of North Africa. CRC Press, Leiden.

Welc, F. 2011. The Third Dynasty open quarry west of the Netjerykhet pyramid complex. ÉtTrav 24: 272-304.

Varol, O. 1992. Taxonomic revision of the Polycyclolithaceae and its contribution to Cretaceous biostratigraphy. Newsletter on Stratigraphy 27 (3): 93-127.

Youssef, M., Cherif, M. O., Boukhary, M., Mohamed, A. 1984. Geological Studies on the Saqqara Area, Egypt. Neues Jahrbuch für Geologie und Paleontologie Abhandlungen 168: 125144. 